\title{
Anaerobic Microorganisms Degrading 3-Methylindole (Skatole) and Indole in Composting Processes
}

\author{
Chikara KOHDA, Tasuke ANDO \\ and Yutaka NAKAI
}

Faculty of Agriculture, Tohoku University, Aoba-ku, Sendai-shi 981

(Received May 20, 1997)

\begin{abstract}
Anaerobic microorganisms that degrade indole or 3-methylindole (skatole) were isolated from porcine or chicken manure composting processes. Numbers of indole or skatoledegrading microorganisms in the pretreatment stage and the finishing stage (mesophilic stages) were larger than those in the fermentation stage (thermophilic stage). Thermophilic anaerobes degrading these compounds were not detected at any stage. Ninety-two isolates were classified into 4 types, i.e. facultatively anaerobic gram-positive cocci, facultatively anaerobic grampositive rods, obligately anaerobic gram-positive endspore-forming rods and facultatively gram -positive endspore-forming rods. Among them, 67 to $91 \%$ were facultatively anaerobic. Utilization of indole or skatole by 24 isolates were quantitatively investigated. All of these isolates degraded indole, but only 8 isolates degraded skatole. Three of skatole-degrading isolates were obligate anaerobic bacteria. This is the first report which indicate the existence of such a type of obligate anaerobes.
\end{abstract}

Anim. Sci. Technol. (Jpn.) 68 (11) : 1045-1051, 1997

Key words : Indole, Skatole, Compost, Anaerobic microorganisms

Compost production processes have been widely used as a waste treatment system. Composting has advantages in stabilizing large volumes of wastes, disinfection of pathogenic organisms, production of fertilizer or soil conditioners. For these reasons, composting possesses a definite and useful role in the implementation of sustainable agriculture $^{26)}$.

Indole and its derivatives such as 3 methylindole (skatole) form a class of toxic recalcitrant $\mathrm{N}$-heterocyclic compounds. They become pollutants after released from cigarette smoke $e^{8,10,17)}$, Coal $\operatorname{tar}^{25)}$, and sewage ${ }^{25)}$ to environment. Although the general level of indoles in living environment is less than the level of immediate toxicity, higher level of skatole cause acute pulmonary edema, emphysema, lung diseases ${ }^{7}$, hemoglobinuria, and hemolysis ${ }^{12\}}$ in cattle and goats. Skatole and indole are main components of the stench of faeces and are resistant to degradation ${ }^{3,6)}$. They are the main cause of unpleasant smell of agricultural wastes. The destruction of malodorous compounds is one of the most important problems for animal wastes treatment. Since the number of anaerobic microorganisms was one tenth of the number of aerobic microorganisms in composting processes ${ }^{24)}$ and anaerobic condition prevail in interior of composts under some circumstances ${ }^{20,27)}$, it is important to examine the anaerobic biodegradation potential of these compounds. In this study, we determined the number of these 
compounds degrading bacteria in compost production process. We also determined the ability of the isolates to degrade these compounds.

\section{Materials and Methods}

\section{Sample}

Samples were collected from compost plants of porcine wastes (scoop type) and poultry wastes (windrow type) at Miyagi Prefecture, Japan. A term of composting was about 6 months in porcine wastes treatment system and about one month in poultry wastes treatment system. About $500 \mathrm{~g}$ of samples were obtained from $30 \mathrm{~cm}$ depth at three stages of composting, i.e. the pretreatment stage, the fermentation stage and the finishing stage, of which temperature was 40,75 and $20^{\circ} \mathrm{C}$ in the porcine waste treatment system and 50,60 and $20^{\circ} \mathrm{C}$ in the poultry waste treatment system, respectively. Moisture of samples were 60,65 and $25 \%$ in respective stage in porcine waste treatment system, and 50,60 and 20\% in poultry waste treatment system. At pretreatment stage, straw was added to the manure as an amendment in porcine waste treatment system and wood chip was added in poultry waste treatment system. Compost recycle was used along with amendment addition in both sys* tems.

\section{Bacterial count}

Anaerobic bacteria were counted by 10 -fold dilution methods using a sterilized dilution solution $^{5)}$ and cultivation by the roll tube method $^{16)}$ modified by Bryant ${ }^{4)}$. The standard tube count was performed with M 2 medium $^{14)}$ added with the compost extracted solution instead of the rumen fluid. Compost extracted solution was prepared as described by Gordon and Rynearson ${ }^{97}$. Numbers of indole and skatole-degrading anaerobic microbes were determined by colony counts on media which contained indole or skatole as a sole source of carbon. The media were modified Hobson's medium ${ }^{14)}$ containing the following nutrients; indole or skatole, $0.3 \mathrm{~g}, \mathrm{NaCl}, 0.9 \mathrm{~g}, \mathrm{KH}_{2} \mathrm{PO}_{4}, 0.45$
$\mathrm{g},\left(\mathrm{NH}_{4}\right)_{2} \mathrm{SO}_{4}, 0.45 \mathrm{~g}, \mathrm{MgSO}_{4}, 0.09 \mathrm{~g}, \mathrm{CaCl}_{2}, 0.09 \mathrm{~g}$, $\mathrm{K}_{2} \mathrm{HPO}_{4}, 0.45 \mathrm{~g}, 0.1 \%$ resazurin solution, $1 \mathrm{ml}$, Lcystein hydrochloride monohydrate, $0.5 \mathrm{~g}$, agar, $18 \mathrm{~g}, \mathrm{pH} 7.5$ in $1 l$ of water. Indole and skatole were dissolved in a minimum amount of methanol and added to the autoclaved medium. As a control set, we prepared the media which contained the equal volume of methanol without indole or skatole. The anaerobic cultures were incubated 14 days at room temperature, $37^{\circ}$ or $56^{\circ} \mathrm{C}$.

\section{The ability of the isolates to degrade indole and skatole}

The isolated strains were incubated in PYG medium $^{15)}$ added with $0.01 \%$ indole or skatole for 7 days at $37^{\circ} \mathrm{C}$. Degradability of the substrates was determined by the rate of disappearance of the substrates. All experiments were conducted in triplicate.

\section{Gas chromatography system and column}

Analyses were performed by Shimadzu gas chromatograph (Model GC-12 A) and Shimadzu integrator (Chromatopac C-R 5A). A 30-m fused-silica capillary column ULBON HR-1701 (Shinwa chemical industries, Ltd., Kyoto, Japan), coated with polyimide resin with a film thickness of $0.53 \mu \mathrm{m}$, was used. The carrier gas was nitrogen at a column flow-rate of 0.1 $\mathrm{kg} / \mathrm{cm}^{2}$. The injector and detector temperatures were set to $300^{\circ} \mathrm{C}$. The temperature gradient was from 120 to $250^{\circ} \mathrm{C}$ at $10^{\circ} \mathrm{C} / \mathrm{min}$. Total analysis time was normally $25 \mathrm{~min}$, including the time for cooling the oven.

Indole and skatole extraction procedure was carried out as described by Jensen $e t a l .{ }^{18)}$ with minor modifications.

\section{Results}

\section{Indole and skatole-degrading anaerobic microbial flora of composting system}

Tables 1 and 2 showed numbers of anaerobic bacteria in compost processes. At the porcine waste treatment system, the level of mesophilic standard tube count decreased after pretreatment stage and increased after fermentation 
Anaerobic Biodegradation of Skatole in Compost

Table 1. Distribution of numbers of anaerobic microbes in composting processes

\begin{tabular}{|c|c|c|c|c|c|c|}
\hline \multirow{2}{*}{ Microbial types } & \multicolumn{3}{|c|}{ Cultivation at room temp. $\left(25-30^{\circ} \mathrm{C}\right)$} & \multicolumn{3}{|c|}{ Cultivation at $37^{\circ} \mathrm{C}$} \\
\hline & $\begin{array}{l}\text { Pretreatment } \\
\text { stage }\end{array}$ & $\begin{array}{c}\text { Fermentation } \\
\text { stage }\end{array}$ & $\begin{array}{l}\text { Finishing } \\
\text { stage }\end{array}$ & $\begin{array}{l}\text { Pretreatment } \\
\text { stage }\end{array}$ & $\begin{array}{l}\text { Fermentation } \\
\text { stage }\end{array}$ & $\begin{array}{l}\text { Finishing } \\
\text { stage }\end{array}$ \\
\hline \multicolumn{7}{|l|}{ Porcine waste } \\
\hline $\mathrm{STC}^{\mathrm{a})}$ & $7.60 \pm 0.15^{b)}$ & 4. $90 \pm 0.16$ & $5.24 \pm 0.16$ & $7.93 \pm 0.04$ & 4. $95 \pm 0.05$ & $7.18 \pm 0.10$ \\
\hline IDM & $3.51 \pm 0.10$ & $2.16 \pm 0.28$ & $3.03 \pm 0.31$ & $3.26 \pm 0.40$ & $2.20 \pm 0.17$ & $2.97 \pm 0.14$ \\
\hline SDM & $2.86 \pm 0.56$ & $<2.00$ & $2.58 \pm 0.27$ & $2.99 \pm 0.46$ & $<2.00$ & $3.60 \pm 0.16$ \\
\hline \multicolumn{7}{|l|}{ Poultry waste } \\
\hline STC & $7.01 \pm 0.08$ & $5.46 \pm 0.15$ & $5.93 \pm 0.06$ & $7.76 \pm 0.12$ & $6.21 \pm 0.19$ & $6.88 \pm 0.21$ \\
\hline IDM & $3.17 \pm 0.19$ & $2.23 \pm 0.40$ & $3.16 \pm 0.10$ & $3.42 \pm 0.07$ & $2.10 \pm 0.17$ & 3. $18 \pm 0.20$ \\
\hline SDM & $2.26 \pm 0.24$ & $2.10 \pm 0.17$ & $3.00 \pm 0.37$ & $2.49 \pm 0.20$ & $<2.00$ & $3.29 \pm 0.23$ \\
\hline
\end{tabular}

${ }^{a}$ Microbial types: STC, standard tube count; IDM, indole-degrading microbe; SDM, skatole-degrading microbe.

b) Data are expressed as mean of $\log _{10} \mathrm{CFU} / \mathrm{g}$ wet weight \pm standard deviation.

Table 2. Distribution of numbers of thermophilic anaerobes in composting processes

\begin{tabular}{|c|c|c|c|}
\hline \multirow[b]{2}{*}{ Microbial types } & \multicolumn{3}{|c|}{ Cultivation at $56^{\circ} \mathrm{C}$} \\
\hline & $\begin{array}{c}\text { Pretreatment } \\
\text { stage }\end{array}$ & $\begin{array}{c}\text { Fermentation } \\
\text { stage }\end{array}$ & $\begin{array}{l}\text { Finishing } \\
\text { stage }\end{array}$ \\
\hline \multicolumn{4}{|l|}{ Porcine waste } \\
\hline $\mathrm{STC}^{\mathrm{a})}$ & $6.12 \pm 0.14^{63}$ & $4.23 \pm 0.04$ & 2.89 \\
\hline IDM & $<2.00$ & $<2.00$ & $<2.00$ \\
\hline SDM & $<2.00$ & $<2.00$ & $<2.00$ \\
\hline \multicolumn{4}{|l|}{ Poultry waste } \\
\hline STC & $4.01 \pm 0.08$ & $2.46 \pm 0.15$ & 2.04 \\
\hline IDM & $<2.00$ & $<2.00$ & $<2.00$ \\
\hline SDM & $<2.00$ & $<2.00$ & $<2.00$ \\
\hline
\end{tabular}

a) Microbial types: STC, standard tube count; IDM, indole-degrading microbe; SDM, skatole-degrading microbe.

b) Data are expressed as $\log _{10}$ mean $\mathrm{CFU} / \mathrm{g}$ wet weight \pm standard deviation.

stage. On the other hand, thermophilic standard tube counts decreased as the treatment progressed. Standard tube counts at $37^{\circ} \mathrm{C}$ cultivation were higher than those at room temperature or $56^{\circ} \mathrm{C}$. Similar pattern was observed in the poultry waste treatment system.

At the porcine waste treatment system, the change of levels of mesophilic indole-degrading microbes was similar to that of mesophilic standard tube counts. The ratio of indole-degrading microbes to standard tube count ranged from 0.01 to $0.001 \%$ in all stages. Mesophilic indole-degrading microbes were not different in number between $37^{\circ} \mathrm{C}$ and room temperature cultivation. Thermophilic indole -degrading microbes were not detected at any processes. Similar results were obtained at the poultry wastes composting processes. The change of numbers of mesophilic skatoledegrading microbes was similar to that of mesophilic indole-degrading microbes. Mesophilic skatole-degrading microbes were slightly lower in number than indole-degrading 


\section{KOHDA, ANDO and NAKAI}

microbes. Thermophilic skatole-degrading microbes were not detected at any process. Similar results were obtained at poultry waste treatment system.

Distribution of bacteria degrading these compounds was investigated among isolates. In the compost plant of porcine waste, four types of bacteria, facultatively anaerobic gram-positive cocci, facultatively anaerobic gram-positive rods, obligately anaerobic gram-positive endspore-forming rods and facultatively gram-positive endspore-forming rods, were isolated (Table 3). Neither of gram-negative bacteria, actinomyces nor fungi

Table 3. Types of indole and skatole-degrading anaerobic microbes isolated from the compost process of porcine waste

\begin{tabular}{|c|c|c|c|c|c|c|}
\hline \multirow{2}{*}{ Microbial flora } & \multicolumn{2}{|c|}{ Pretreatment stage } & \multicolumn{2}{|c|}{ Fermentation stage } & \multicolumn{2}{|c|}{ Finishing stage } \\
\hline & No. of isolates & $\%^{n)}$ & No. of isolates & $\%$ & No. of isolates & $\%$ \\
\hline \multicolumn{7}{|c|}{ Indole-degrading bacteria } \\
\hline $\mathrm{FPC}^{\mathrm{b})}$ & 8 & 29.6 & 3 & 20.0 & 2 & 13.3 \\
\hline FPR & 5 & 18.5 & 4 & 26.7 & 5 & 33.3 \\
\hline OPER & 10 & 37.0 & 7 & 46.7 & 5 & 33.3 \\
\hline FPER & 4 & 14.8 & 1 & 6.7 & 3 & 20.0 \\
\hline \multicolumn{7}{|c|}{ Skatole-degrading bacteria } \\
\hline FPC & 6 & 20.0 & - & - & 7 & 28.0 \\
\hline FPR & 16 & 53.3 & - & 一 & 13 & 52.0 \\
\hline OPER & 8 & 26.7 & - & - & 5 & 20.0 \\
\hline FPER & 0 & 0.0 & - & - & 0 & 0.0 \\
\hline
\end{tabular}

a) Percentage of total isolates.

b) Microbial flora: FPC, facultatively anaerobic gram-positive cocci ; FPR, faculiatively anaerobic grampositive rods; OPER, obligately anaerobic gram-positive endospore-forming rods; FPER, facultatively anaerobic gram - positive endospore-forming rods.

Table 4. Types of indole and skatole-degrading anaerobic microbes isolated from the compost process of poultry waste

\begin{tabular}{|c|c|c|c|c|c|c|}
\hline \multirow[t]{2}{*}{ Microbial flora } & \multicolumn{2}{|c|}{ Pretreatment stage } & \multicolumn{2}{|c|}{ Fermentation stage } & \multicolumn{2}{|c|}{ Finishing stage } \\
\hline & No. of isolates & $\%^{\mathrm{a})}$ & No. of isolates & $\%$ & No. of isolates & $\%$ \\
\hline \multicolumn{7}{|c|}{ Indole-degrading bacteria } \\
\hline $\mathrm{FPC}^{\mathrm{b})}$ & 7 & 33.3 & 5 & 41.7 & 4 & 23.5 \\
\hline FPR & 6 & 28.6 & 5 & 41.7 & 6 & 35.3 \\
\hline OPER & 5 & 23.8 & 2 & 16.6 & 5 & 29.4 \\
\hline FPER & 3 & 14.3 & 0 & 0.0 & 2 & 11.8 \\
\hline \multicolumn{7}{|c|}{ Skatole-degrading bacteria } \\
\hline FPC & 5 & 35.7 & - & - & 8 & 38.1 \\
\hline FPR & 4 & 28.6 & - & - & 7 & 33.3 \\
\hline OPER & 2 & 14.3 & - & - & 2 & 9.5 \\
\hline FPER & 3 & 21.4 & - & - & 4 & 19.0 \\
\hline
\end{tabular}

a) Percentage of total isolates.

b) Microbial flora: FPC, facultatively anaerobic gram-positive cocci : FPR, facultatively anaerobic grampositive rods; OPER, obligately anaerobic gram-positive endospore-forming rods; FPER, facultatively anaerobic gram-positive endospore-forming rods. 
were detected at any stage. The dominant indole-degrading bacteria was obligately anaerobic gram-positive endspore-forming rods in all stages. The dominant skatole-degrading bacteria was facultatively anaerobic gram-positive rods. Facultatively anaerobic gram-positive endspore-forming rods were not isolated among skatole-degrading bacteria.

In the compost plant of poultry wastes, the same types of bacteria were investigated (Table 4). The dominant indole-degrading bacteria was facultatively anaerobic gram-positive cocci in the pretreatment and fermentation stages and was facultatively anaerobic gram-positive rods in fermentation and finishing stages. The dominant skatole-degrading bacteria was facultatively anaerobic gram-positive cocci. Obligately anaerobic gram-positive endspore-forming rods were the smallest among skatole-degrading bacteria in number.

The ability of the isolates to degrade indole and skatole

All of 24 isolates degraded indole and 8 isolates degraded skatole (Table 5). The largest rate of disappearance of indole $(28.64 \%)$ was shown by facultatively gram-positive endspore-forming rods HA 2-4 and smallest (3.30\%) was shown by obligately anaerobic gram-positive endspore-forming rods IEI-14. On the other hand, the largest rate of disappearance of skatole $(11.91 \%)$ was shown by obligately anaerobic gram-positive endsporeforming rods A-3 and smallest (3.64\%) was shown by obligately anaerobic gram-positive endspore-forming rods A-4.

\section{Discussion}

Indole or skatole-degrading bacteria appeared during the mesophilic stage, and their numbers decreased in the thermophilic stages. After the temperature lowered, they reappeared. This pattern was commonly investigated for mesophilic bacteria in composts $^{24)}$. A similar pattern was investigated in standard tube counts in this ex-
Table 5. Utilization of indole and skatole by the isolated strains

\begin{tabular}{|c|c|c|c|}
\hline & \multirow{2}{*}{ Strain } & \multicolumn{2}{|c|}{ Rates of disappearance $(\%)$} \\
\hline & & Indole & Skatole \\
\hline \multicolumn{4}{|l|}{$F P C^{a)}$} \\
\hline & $A-1$ & 22.23 & 0.00 \\
\hline & A 1-3 & 26.19 & 0.00 \\
\hline & HA 2-1 & 17.05 & 0.00 \\
\hline & $\mathrm{HA} 2-3$ & 20.26 & 3.93 \\
\hline & $S 2-10$ & 27.36 & 11.69 \\
\hline \multicolumn{4}{|l|}{ FPR } \\
\hline & A $1-2$ & 11.99 & 8.09 \\
\hline & HA $2-2$ & 23. 48 & 0.00 \\
\hline & $S 2-11$ & 27.94 & 10.64 \\
\hline \multicolumn{4}{|l|}{ OPER } \\
\hline & $A-3$ & 16.53 & 11.91 \\
\hline & $A-4$ & 6.21 & 3.64 \\
\hline & $A-13$ & 11.06 & 0.00 \\
\hline & A $1-4$ & 24.89 & 0.00 \\
\hline & A $1-5$ & 10.73 & 0.00 \\
\hline & A $1-6$ & 16.12 & 4.76 \\
\hline & IEI-2 & 11. 38 & 0.00 \\
\hline & IEI -5 & 8.19 & 0.00 \\
\hline & IEI-14 & 3. 30 & 0.00 \\
\hline & I 2 I-5 & 8.79 & 0.00 \\
\hline & $121-7$ & 23.23 & 0.00 \\
\hline \multicolumn{4}{|l|}{ FPER } \\
\hline & HA 2-4 & 28.64 & 0.00 \\
\hline & HA 2-5 & 11.38 & 0.00 \\
\hline & I $2 \mathrm{I}-13$ & 15.88 & 0.00 \\
\hline & I2 I-14 & 27.05 & 0.00 \\
\hline & I 3 I-1 & 8.71 & 10.14 \\
\hline
\end{tabular}

a) Microbial type: FPC, facultatively anaerobic gram-positive cocci; FPR, facultatively anaerobic gram-positive rods; OPER, obligately anaerobic gram-positive endospore-forming rods ; FPER, facultatively anaerobic gram-positive endosporeforming rods.

periment. Skatole-degrading microbes were slightly lower in number than indole-degrading microbes. This result agrees with the observation that not all indole-degrading isolates were capable of degrading skatole but skatoledegrading isolates were all capable of degrading indole (Table 5). There is a possibility that mesophilic microbes were replaced by 
thermophilic microbes during thermophilic stage. Then, we attempted to determine the numbers of thermophilic indole or skatole-degrading microbes. When cultivation temperature was set to $56^{\circ} \mathrm{C}$, they were not detected at any stages (Table 2). In addition to such experiments, we also carried out the enrichment culture of thermophilic indole and skatole--degrading microbes and did not isolate them (data not shown). These results indicated that few thermophilic anaerobic skatole and indoledegrading microbes were present in the compost. A striking difference was not recognized between plants of porcine wastes and poultry wastes. Kamath and Vaidyanathan ${ }^{19)}$ reported Aspergillus niger which did not grow when indole was used as sole source of carbon and nitrogen but cometabolized indole when glucose and nitrate were present in the medium. Since such microbes could not be grow on the medium used in the present work, numbers of indole or skatole-degrading microbes may higher than the present results.

Almost all isolates degrading these compounds were facultative anaerobes (Tables 3 and 4). Strict aerobic or facultatively anaerobic microbes were known to degrade indole or skatole under aerobic condition ${ }^{23)}$. The present study indicated that many types of bacteria were capable of degrading indole or skatole also under anaerobic condition. Anaerobic degradation of indole shown by cultivation of municipal sewage sludges or after enrichment cultures ${ }^{2,11,12,21,22)}$. Desulfobacterium indolicum, a sulfate-reducing bacterium, which was isolated from marine sediment, was the definite species to be shown to use indole as the sole electron donor and carbon source ${ }^{\text {D. }}$. The present paper is the first report which showed that obligate anaerobes could anaerobically degrade skatole. We are clarifying the pathway for the biodegradation of indole or skatole by the isolates. The information should be useful in determining the fate of these chemicals in animal manure treatment systems.

\section{References}

1) Bak F, Widdel F. Anaerobic degradation of indolic compounds by sulfate-reducing enrichment cultures, and description of Desulfobacterium indolicum gen. nov. Arch. Microbiol., 146 : 170-176. 1986.

2) Berry DF, Madsen EL, Bollag JM. Conversion of indole to oxindole under methanogenic conditions. Appl. Environ. Microbiol., 53 : 180-182. 1987.

3) Bethea RM, Narayan RS. Identification of beef cattle beeflot odors. Trans. Am. Soc. Agric. Eng., $15: 1135-1137.1972$.

4) Bryant MP. Commentary on the Hungate technique for culture of anaerobic bacteria. Ann. J. Clin. Nutr., 25 : 1324-1328. 1972.

5) Bryant MP, Burkey LA. Cultural methods and some characteristics of some of the more numerous groups of bacteria in the bovine rumen. J. Dairy Sci., 36 : 205-217. 1953.

6) Burnett WE. Air pollution from animal waste: determination of malodors by gas chromatography and organoleptic techniques. J. Environ. Sci. Technol., 3 : 744-749. 1969.

7) Carlson JR, Yokoyama MT, Dickinson EO. Induction of pulmonary edema and emphysema in cattle and goats with 3-methylindole. Science, $176: 298-299.1972$.

8) Florin I, Rutberg L, Curvall M, Enzell $C R$. Screening of tabacco smoke constituents for mutagenicity using the Ame's test. Toxicology, $18: 219-232.1980$.

9) Gordon RE, Rynearson TK. Maintenance of strain of Bacillus species. In : Culture Collections: Perspectives and Problems. (Martin SM ed. 118-128. University of Toronto Press. Toronto. 1962.

10) Grob K, Voellmin JA. GC-MS analysis of the semi-volatiles of cigarette smoke. J. Chromatogr. Sci., 8 : 218-220. 1970.

11) Gu JD, Berry DF, Degradation of substituted indoles by indole-degrading methanogenic consortium. Appl. Environ. Microbiol., 57 : 2622-2627. 1991.

12) Gu JD, Berry DF. Metabolism of 3Methylindole by a methanogenic consortium. Appl. Environ. Microbiol., 58 : 2667-2669. 1992.

13) Hammond AC, Carlson JR, Breeze RC. Indole toxicity in cattle. Vet. Rec., $107: 344-346.1980$.

14) Hobson PN. Rumen bacteria. In : Methods in 
Microbiology vol. 3 B. (Norris JR, Ribbons DW eds.) 133-149. Academic Press. London. 1974.

15) Holdeman LV, Cato EP, Moore WEC. Anaerobic Laboratory Manual, 4th ed., 1-156. Virginia Polytech. Inst. and Univ., Blaoksburg, Virginia. 1977.

16) Hungate RE. A roll tube method for cultivation of strict anaerobes. In : Methods in Microbiology vol. 3 B. (Norris JR, Ribbons DW eds.) 118-132. Academic Press. London. 1974.

17) Ishiguro S, Sugawara S. Comparison of smoke components in the semi-volatile phase from lamina and midrib cigarette of flue-cured tabacco leaves. Agric. Biol. Chem., 42 : 15271531. 1978.

18) Jensen MT, Jensen BB. Gas chromatographic determination of indole and 3-methylindole (skatole) in bacterial culture media, intestinal contents and faeces. J. Chromatogr., B 655: 275-280. 1994.

19) Kamath AV, Vaidyanathan CS. New pathway for the Biodegradation of indole in Aspergillus niger. Appl. Environ. Microbiol., $56: 275-280$ 1990.

20) Kochtitzky OW, Seaman WK, Wiley JS. Mu- nicipal composting research at Johnson City, Tennessee. Compost Sci., 9 : 5-16. 1969.

21) Madesen EL, Francis AJ, Bollag JM. Environmental factors affecting indole metabolism under anaerobic conditions. Appl. Environ. Microbiol., 54 : 74-78. 1988.

22) Madesen EL, Bollag JM. Pathway of indole metabolism by a denitrifying microbial community. Arch. Microbiol, 151:71-76. 1989.

23) Müler HE. Production and degradation of indole by gram-negative bacteria. Zbl. Bakt. Hyg., A 261 : 1-11. 1986.

24) Nakai $Y$. Microbial fora in animal manure recycle systems. Proc. The 8th AAAP Animal Science Congress, I : 89-98. 1996.

25) Ochiai $M$, Wakabayashi $K$, Sugimura $T$, Nagao M. Mutagenicities of indole and 30 derivatives after nitrite treatment. Mutat. Res., 172:189197. 1986.

26) Ruttan VW. Commentary : Sustainability is not enough. Am. J. Altern. Agric., 3 : 128-130. 1988.

27) Wiley JS, Spillane JT. Refuse-sludge composting in windrows and bins. Compost Sci., 2 : $18-$ 25. 1962 .

\title{
コンポスト処理過程における3ーメチルインドール（スカトール） またはインドールを分解する嫌気性菌の動態解析
}

\author{
幸田 力・安藤太助・中井 裕 \\ 東北大学農学部, 仙台市青葉区 981
}

\begin{abstract}
ブタ排泄物执よびニワトリ排泄物のコンポスト形成過程から難分解性の悪莫物質インドールおよび 3ーメチルインドール (スカトール) を咏気的に分解する微生物の動態解析を行った. インドール分解菌, スカトール分解菌と6に発酵過程（高鼬期）よりも前処理過程（中温期）および製品コンポストに菌数 が多いことが示された，また，好熱性のインドールもしくはスカトール分解菌はいずれの処理過程から あ倹出されなかった。これらの化合物の分解菌を 92 株分離したこころ, 通性婵気性グラム晹性球菌, 通 性嫌気性グラム陽性桿菌, 通性嫌気性グラム陽性芽胞柏菌, 偏性嫌気性グラム陽性芽胞桿菌の4タイプ の菌群に分類された，分離株の大部分 (67-91\%) は通性嫝気性菌であった．分離株はすべてインドール 分解能を有していたが， スカトール分解能を有する株は 8 株のみであった８株のスカトール分解菌の

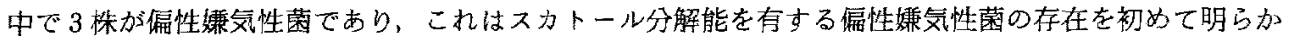
にするものである.
\end{abstract}

日畜会報, $68(11): 1045-1051,1997$ 